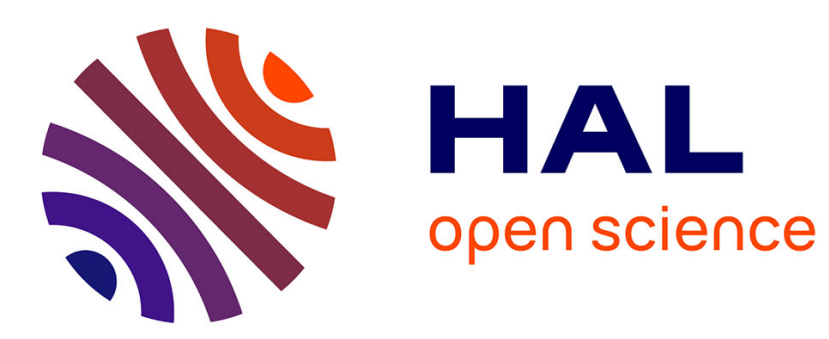

\title{
Integration of a relocatable ocean model in the Mediterranean Forecasting System
}

\author{
A. Russo, A. Coluccelli
}

\section{To cite this version:}

A. Russo, A. Coluccelli. Integration of a relocatable ocean model in the Mediterranean Forecasting System. Ocean Science Discussions, 2006, 3 (5), pp.1609-1621. hal-00298427

\section{HAL Id: hal-00298427 \\ https://hal.science/hal-00298427}

Submitted on 4 Oct 2006

HAL is a multi-disciplinary open access archive for the deposit and dissemination of scientific research documents, whether they are published or not. The documents may come from teaching and research institutions in France or abroad, or from public or private research centers.
L'archive ouverte pluridisciplinaire HAL, est destinée au dépôt et à la diffusion de documents scientifiques de niveau recherche, publiés ou non, émanant des établissements d'enseignement et de recherche français ou étrangers, des laboratoires publics ou privés. 
Ocean Sci. Discuss., 3, 1609-1621, 2006

www.ocean-sci-discuss.net/3/1609/2006/

(C) Author(s) 2006. This work is licensed

Relocatable model in MFS

\section{A. Russo and \\ A. Coluccelli}

\section{Integration of a relocatable ocean model in the Mediterranean Forecasting System}

\section{A. Russo and A. Coluccelli}

Department of Marine Science, Polytechnic University of Marche, Ancona, Italy

Received: 2 August 2006 - Accepted: 10 September 2006 - Published: 4 October 2006

Correspondence to: A. Russo (a.russo@univpm.it)

\section{Title Page}

\section{Full Screen / Esc}

Printer-friendly Version

Interactive Discussion 


\section{Abstract}

The MFS (Mediterranean Forecasting System) project and its follower MFSTEP (Mediterranean ocean Forecasting System - Towards Environmental Prediction) are being covering the Mediterranean Sea with operational Ocean General Circulation

5 Models (OGCMs) at horizontal resolution varying from about $12 \mathrm{~km}$ till 2005 to $6.5 \mathrm{~km}$ in 2006 (reaching $3 \mathrm{~km}$ with some regional models and $1.5 \mathrm{~km}$ for few shelf models). Heat, water and momentum fluxes through the air-sea interface are derived from the European Center for Medium-range Weather Forecast (ECMWF) output at $0.5^{\circ}$ horizontal resolution. Such horizontal resolutions could be not able to provide the needed forecast accuracy in some cases (localized emergencies at sea, e.g. oil spill; need for high resolution current forecasts, e.g. offshore works). A solution to this problem is represented by relocatable models able to be rapidly deployed and to produce forecasts starting from the MFS products. The Harvard Ocean Prediction System (HOPS) has been chosen as base of the relocatable model and it has been interfaced with the 15 MFSTEP OGCM and one regional model. The relocatable model has demonstrated capability to produce forecasts within $2-3$ days in many cases, and more rapid implementation may be obtained.

\section{Introduction}

The Mediterranean ocean Forecasting System Towards Environmental Prediction (MFSTEP) project (Coppini et al., 2006) ${ }^{1}$ aimed to develop an efficient Near Real Time observing system in conjunction with modelling and prediction capabilities with the scope

\footnotetext{
${ }^{1}$ Coppini, G., Pinardi, N., Manzella, G. M. R., Tziavos, C., Larnicol, G., Poulain, P. M.,
} Send, U., Raicich, F., De Mey, P., Lascaratos, A., Katsafados, P., Pytharoulis, I., Zavatarelli, M., Triantafyllou, G., Zodiatis, G., and Petit De La Villeon, L.: The Mediterranean Forecasting System second phase of implementation: Marine Core and downstream Services, Ocean Sci. Discuss., in preparation, 2006.

\section{OSD}

3, 1609-1621, 2006

Relocatable model in MFS

\section{A. Russo and}

A. Coluccelli

\section{Title Page}

\section{Full Screen / Esc}

Printer-friendly Version

Interactive Discussion 
to better assess the state of marine environment and to deal with resource management issues and emergencies in the coastal areas. An advanced data assimilation scheme has been developed to optimally merge observations into the numerical modeling system. The monitoring network in the Mediterranean Sea has been greatly

5 improved and the synoptic coverage of satellite data has been also used for assimilation into the numerical models. An operational set of general circulation models has been implemented to predict the dynamical field variables from the basin to the shelf scale at different time and space resolutions. A downscaling of observational and numerical modeling information is realized from the $6.5 \mathrm{~km}$ horizontal resolution of the 10 basin-scale Mediterranean model up to $1.5 \mathrm{~km}$ horizontal resolution of the shelf models. The MFSTEP project gives great emphasis to the exploitation of the forecasting products. End-users, among others, should be the coastal guard services and the environmental agencies involved in the protection of the marine coastal waters. Software interfaces have been implemented between forecast products and oil spill models, dis15 persion models, relocatable emergency systems, search and rescue models and fish stock observing systems. The advantage of relocatable models use come from the observation that MFSTEP OGCM and regional models are not able to grant the needed forecast accuracy in some special cases, when high resolution forecasts are required. As example, the OGCM $6.5 \mathrm{~km}$ horizontal resolution makes difficult to obtain accurate 20 forecast in areas with several small islands, like in the Aegean and Adriatic Seas, and more in general in coastal areas (which are usually the ones generating maximum concern from the environmental and socio-economic point of view). The problem can become particularly relevant in cases such as oil spills that could impact coastal areas.

\section{Brief description of MFSTEP models}

25 The Mediterranean Forecasting System (Pinardi et al., 2003) has been recently improved to produce forecast on a daily basis. Every day a new 10-days forecast is released. A re-analysis of the past fifteen days is computed once a week. It includes a

OSD

3, 1609-1621, 2006

Relocatable model in MFS

A. Russo and

A. Coluccelli

Title Page

Abstract Introduction

Conclusions

Tables References Figures

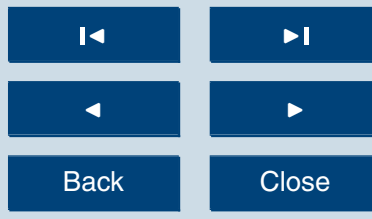

Full Screen / Esc

Printer-friendly Version

Interactive Discussion

EGU 
data assimilation scheme and all the available satellite and in-situ datasets are assimilated in order to achieve the better estimate of the state of the ocean. A combination of weekly analyses and daily simulations is used to initialize the model for the production of the forecast. The numerical model is an implementation of OPA (Ocean PArallelise; 5 Madec et al., 1998) at $1 / 16^{\circ} \times 1 / 16^{\circ}$ horizontal resolution and 72 unevenly spaced vertical levels. It uses an implicit free-surface approximation to the primitive equations and thus the sea surface elevation is a prognostic variable and the water flux can be parameterized. The lateral boundary includes a so-called Atlantic Box extending to $-18.125^{\circ} \mathrm{W}$. The model salinity and temperature are relaxed to the climatology along 10 the boundary of the Atlantic Box. The wind stress and heat fluxes in this region are taken from a monthly mean climatology. In the Mediterranean basin the fluxes of momentum and heat are computed by an air-sea interaction submodel following Castellari et al. (1998). The atmospheric forcing fields are from 6-hour operational analyses of the European Centre for Medium-Range Weather Forecasts (ECMWF; Bouttier and 15 Rabier, 1998). The output of the model is released as NetCDF files (Network Common Data Form; Rew et al., 1997) and contains potential temperature and salinity fields, net downward heat flux, solar radiation flux, net upward water flux, sea surface height, wind stress and velocity fields. All parameters are expressed as daily averages. The regional model of the Adriatic Sea (AREG) is an implementation of POM (Princeton Ocean 20 Model; Blumberg and Mellor, 1987) as described in Zavatarelli and Pinardi (2003), operational in the framework of ADRICOSM project (funded by the Italian Ministry for Environment). POM is a free-surface, three-dimensional finite-difference numerical model based on the primitive equations with Boussinesq and hydrostatic approximations. The horizontal resolution is about $5 \mathrm{~km}$ in both directions and the vertical grid consists of 21 sigma layers. The open boundary is located south of the Otranto Channel, where the model is nested with the basin-scale model of the Mediterranean Sea, through a simple off-line, one-way nesting technique (Oddo et al., 2005). The air-sea fluxes are computed from the 6-hours operational analysis of ECMWF at $0.5^{\circ}$ horizontal resolution. An important element of the Adriatic Sea dynamics is represented by the Po River

OSD

3, 1609-1621, 2006

Relocatable model in MFS

A. Russo and

A. Coluccelli

Title Page

Abstract Introduction

Conclusions

Tables References Figures
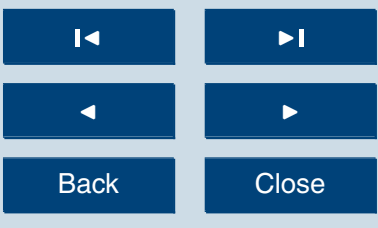

Full Screen / Esc

Printer-friendly Version

Interactive Discussion

EGU 
runoff. The daily averages of river discharge taken from the measurements of the Po River Authority are used as input to the model. A 7-days forecast is produced once a week and it is initialized by the last day of simulation of the past seven days. The output is released as NetCDF file and contains daily means of temperature, salinity, sea 5 surface height, velocity, wind stress and heat fluxes. The Skiron/Eta system produces every day a 5-days forecast of atmospheric fields at $10 \mathrm{~km}$ horizontal resolution. The output is released as hourly data and can be used to force regional and shelf models at high resolution in time and space. A detailed description of the model implementation can be found in Kallos (1997), Nickovic et al. (1998), Papadopoulos et al. (2002).

10 For the Adriatic Sea (and Italian seas in general), the fluxes through the air-sea interface can be derived by atmospheric fields at $6.5 \mathrm{~km}$ horizontal resolution produced by the Limited Area Model Italy (LAMI), implementation of Lokall Model (Steppeler et al., 2003), operated by the Hydro-Meteorological Service of the Environmental Agency of Emilia-Romagna Region, (ARPA-SIM, Bologna, Italy) in agreement with the Meteoro15 logical Office of the Italian Air Force and with Piemonte Region. The output is released every $12 \mathrm{~h}$ for the next $72 \mathrm{~h}$ as 3-hourly data (higher timely resolution outputs can be required).

\section{The relocatable model}

The Harvard Ocean Prediction System (HOPS) has been chosen as basis for the relo20

because it contains various program packages which are helpful for setting up the
model domain and the grid, conditioning of bathymetry, management of observational data, objective analysis, preparation of assimilation fields, etc. (Lozano et al., 1996; Robinson 1999). The HOPS model solves the primitive equations, assuming that the

is hydrostatic and the Boussinesq approximation is valid (Spall and Robinson, 1990). In the horizontal, open boundary conditions are applied, and the vertical boundary conditions are that of no normal flow at the surface (rigid-lid) and at the bottom. The
OSD

3, 1609-1621, 2006

Relocatable model in MFS

A. Russo and

A. Coluccelli

Title Page

Abstract

Introduction

Conclusions

Tables

References

Figures

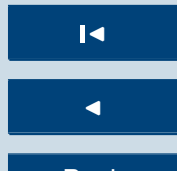

$>$ I

Back

Close

Full Screen / Esc

Printer-friendly Version

Interactive Discussion

EGU 
horizontal coordinates may be selected either Cartesian, rotated Cartesian, spherical or rotated spherical. For the vertical coordinate, the following options are offered: constant depth levels, sigma, double-sigma, or hybrid. Horizontal sub-gridscale processes are parameterized by conventional eddy viscosity and diffusivity or by Shapiro filtering 5 (Shapiro, 1970) of momentum, tracers, vorticity and transport. Vertical diffusion is formulated in terms of a Richardson-number dependent scheme proposed by Pacanowski and Philander (1981). Near horizontal and vertical rigid boundaries, Rayleigh friction is applied using a Gaussian weighting of distance from the bottom or the coast, respectively (Lermusiaux, 1997).

\section{Relocatable system applications}

\subsection{MFSTEP to relocatable model interfaces}

Using objective analysis (Carter and Robinson, 1987), the initial mass field of the model is generated by mapping temperature and salinity produced by MFSTEP ocean models on the model grid. The initial velocity field is defined in terms of the corresponding geostrophic currents. During the integration of the model, new data (from MFSTEP models and, if available, from observations) may be assimilated using Optimum Interpolation (Robinson et al., 1998), a rapid and robust technique. Assimilation techniques may also be used to provide data along the open boundaries. An important requirement for the application of the relocatable model is the ability to extract ocean data and atmospheric forcing fields from the MFSTEP model outputs, whatever the relocatable model domain and the required period of forecast (or simulation run). Some simple and easy-to-use interfaces between the source data and the input to the relocatable model have been developed. The code is written in Fortran 90/95 to assure portability from one system to another. Also the possibility of a high level of optimization makes the code very suitable for managing a great amount of data in a short time. The user interface has been developed as Linux Shell scripts, with the advantage of an easy
OSD

3, 1609-1621, 2006

Relocatable model in MFS

A. Russo and

A. Coluccelli

\section{Title Page}

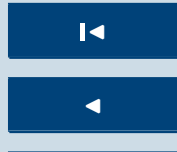

\section{Full Screen / Esc}

Printer-friendly Version

Interactive Discussion 
customization and code maintenance plus the possibility of the automatization of the whole task. The marine fields can be extracted from the Mediterranean model (OPA) or from the Adriatic Regional model (AREG). The needed fields are in-situ temperature and salinity. Since OPA output contains a field of potential temperature (instead 5 of temperature), a conversion to in-situ temperature has been applied following the formulation given by Fofonoff and Millard (1983). The fluxes through the air-sea interface are derived from the Skiron datasets, which are released in GRIB format. A preliminary extraction and conversion in binary format is carried out making the use of "wgrib", a portable grib decoder developed by the NCEP/NCAR Reanalysis Project and freely 10 available at http://www.cpc.ncep.noaa.gov/products/wesley/wgrib.html. When working in the AREG (or other Italian seas) domain, fluxes through the air-sea interface are derived from the LAMI datasets (released in GRIB and NetCDF formats) through Matlab $\mathrm{TM}$ routines. The computed fields that serve as input to HOPS are the wind stress, the total heat flux, the water flux (E-P) and the shortwave radiation field. The wind stress 15 computation uses a drag coefficient calculated as a function of wind velocity and of the air-sea temperature difference, according to Hellermann and Rosenstein (1983). In all cases the user can specify the limits in longitude and latitude of the area of interest, and the timing, so greatly reducing the size of the output file and avoiding the processing of unused data.

\subsection{Example of forecast improvement}

Several simulations were conducted both with MFS OGCMs and ADRICOSM AREG. The most interesting results came from simulations conducted in the Adriatic Sea during summer 2004 (when a quantity of in situ and remote sensing observations were available). Such area was not fully covered by the MFS OGCM operational at that time 25 (MOM), so initialization fields for the relocatable system were deduced by the operational regional model (AREG). The horizontal resolution of the relocatable model was chosen at $1 \mathrm{~km}$ (AREG one being $5 \mathrm{~km}$ ) on a $221 \times 201$ Cartesian grid, with 20 sigma terrain-following levels in vertical. Surface air-sea heat, water and momentum fluxes

OSD

3, 1609-1621, 2006

Relocatable model in MFS

A. Russo and

A. Coluccelli

Title Page

Abstract Introduction

Conclusions

Tables References

Figures

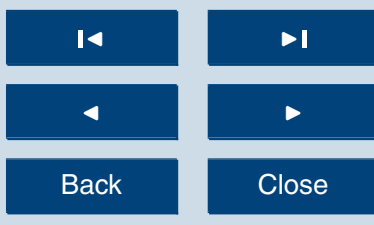

Full Screen / Esc

Printer-friendly Version

Interactive Discussion

EGU 
were extracted by LAMI outputs (AREG computed surface fluxes interactively from the coarser resolution ECMWF atmospheric model), then interpolated on the relocatable system grid. Initialization of the relocatable system was derived by the AREG hindcast on the 15th of June, 2004. Then AREG hindcasts were assimilated on June 16, 17, 19,

521 and 23, keeping stable the run and updating boundary values. In-situ temperature and salinity data collected around the Monte Conero (the northwestern promontory in Fig. 1) were assimilated on the 25th of June, and any assimilation was performed afterward. Cross-validation is showed in Fig. 1; here surface fields (salinity and currents) from the relocatable model, in situ salinity data and SeaWIFS ocean colour (higher

10 SeaWIFS values were clearly associated, as typical for the western Adriatic Sea, with freshwaters) show a consistent picture on the 29th of June: all of them indicate an anticyclonic feature, which detached from the northwestern promontory (according to both the previous SeaWIFS images and model simulation). Examining the comprehensive set of data and simulations, it resulted that the simulations conducted with the relocatable model showed some forecast improvements over AREG when in situ data were not assimilated, and very good agreement with real features during one week after the in situ data assimilation on the 25th of June. As example, in Fig. 2 surface salinity and currents from both AREG and the relocatable model, and SeaWIFS ocean colours are compared on the 2nd of July, 2004 (i.e. 7 days after the last assimilation). The surface salinity patterns and features forecasted by the relocatable system resembles very closely the ocean colours detected by SeaWIFS, showing evident improvements vs. the AREG hindcast.

\section{Conclusions}

As general conclusion, the relocatable system, with its higher horizontal resolution 25 (of air-sea fluxes, too) than regional and OGCM operational models, is able to grant improvement of the forecast accuracy. Relocatable models represent an affordable solution for increasing forecast accuracy in limited area for limited time. This would

OSD

3, 1609-1621, 2006

Relocatable model in MFS

A. Russo and

A. Coluccelli

Title Page

Abstract Introduction

Conclusions

Tables References

Figures

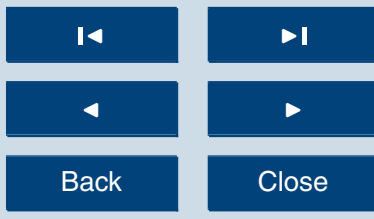

Full Screen / Esc

Printer-friendly Version

Interactive Discussion

EGU 
be particularly useful in cases such as emergencies and offshore works to be carried out within short alert time. Best results were obtained with assimilation of in situ data, so data assimilation capability appears to be a relevant characteristics for relocatable models. In fact, experiments showed that, by assimilating some in-situ data in criti5 cal positions, accurate forecasts could be released during at least one week in shelf areas, too. Forecasts can be released in most cases within $72 \mathrm{~h}$ from request, and this limit could be further reduced by improving procedures and by availability of faster computers and highly exercised operators.

Acknowledgements. The authors thank many colleagues involved in this work, especially 10 A. R. Robinson and his group at Harvard University (Cambridge, MASS, USA) for the HOPS model, N. Pinardi (MFSTEP project leader) and her group at INGV Bologna (Italy) for the OPA and AREG operational forecasts, G. Kallos and his group at University of Athens (Greece) for the Skiron operational forecasts, S. Tibaldi and his group at ARPA-SIM E. Romagna (Bologna, Italy) for the LAMI operational forecasts, E. Paschini and his group at ISMAR-CNR Ancona

15 (Italy) for the R/V Dallaporta surveys, R. Santoleri and her group at ISAC-CNR Rome (Italy) for the SeaWIFS images, R. Onken at GKSS (Germany) for his determining contribution in the ideation and design phase. This work has been partly supported by the "Mediterranean ocean Forecasting System Towards Environmental Prediction" (MFSTEP) project, EC Contract EVK3-CT2002-00075.

\section{References}

Blumberg, A. F. and Mellor, G. L.: A description of a three-dimensional coastal ocean circulation model, in: Three-dimensional Coastal Ocean Models, edited by: Heaps, N. S., Coastal and Estuarine Sciences, 4, Amer. Geophys. Union, Washington D.C., 1-16, 1987.

Bouttier, F. and Rabier, F.: The operational implementation of 4DVAR, ECMWF Newsletter, 78, http://www.ecmwf.int/publications/newsletters, 72-76, 1998.

Carter, E. F. and Robinson, A. R.: Analysis models for the estimation of oceanic fields, J. Atmosph. Ocean. Technol., 4, 49-74, 1987.

Castellari, S., Pinardi, N., and Leaman, K.: A model study of air-sea interactions in the Mediterranean Sea, J. Mar. Syst., 18, 89-114, 1998.

\section{OSD}

3, 1609-1621, 2006

Relocatable model in MFS

\section{A. Russo and}

A. Coluccelli

\section{Title Page}

\section{Full Screen / Esc}

Printer-friendly Version

Interactive Discussion

EGU 
Fofonoff, N. P. and Millard, R. C.: Algorithms for computation of fundamental properties of seawater, UNESCO Tech. Pap., Marine Sci., No. 44, 42-45, UNESCO, Paris, 1983.

Hellermann, S. and Rosenstein, M.: Normal monthly wind stress over the world ocean with error estimates, J. Phys. Oceanogr, 13, 1093-1104, 1983.

5 Kallos, G.: The regional weather forecasting system SKIRON, Proceedings of the Symposium on Regional Weather Prediction on Parallel Computer Environments, 15-17 October 1997, Athens, Greece, 1997.

Lermusiaux, P. F. J.: Error subspace data assimilation methods for ocean field estimation: theory, validation and applications, Harvard Open Ocean Model Reports, No. 55, Harvard

10 University, Cambridge, MA, 1997.

Lozano, C. J., Robinson, A. R., Arango, H. G., Gangopadhyay, A., Sloan, Q., Haley, P. J., Anderson, L., and Leslie, W. G.: An interdisciplinary ocean prediction system: assimilation startegies and structured data models, in: Modern Approaches to Data Assimilation in Ocean Modeling, edited by: Malanotte-Rizzoli, P., Elsevier Oceanography Series, 61, Elsevier, Amsterdam, NL, 413-452, 1996.

Madec, G., Delecluse, P., Imbard, M., and Levy, C.: OPA8.1 Ocean general Circulation Model reference manual, Note du Pole de modélisazion, No. 11, Institut Pierre-Simon Laplace (IPSL), France, 1998.

Nickovic, S., Mihailovic, D., Rajkovic, B., and Papadopoulos, A.: The weather forecasting sys20 tem SKIRON, Vol. II: Description of the Model, Department of Physics, University of Athens, 1998.

Oddo, P., Pinardi, N., and Zavatarelli, M.: A numerical study of the interannual variability of the Adriatic Sea (2000-2002), Sci. Tot. Env., 353, 39-56, 2005.

Pacanowski, R. C. and Philander, S. G. H.: Parameterization of vertical mixing in numerical models of tropical oceans, J. Phys. Oceanogr., 11, 1443-1451, 1981.

Papadopoulos, A., Katsafados, P., and Kallos, G.: Regional weather forecasting for marine application, GAOS, 8, No. 2-3, 219-237, 2002.

Pinardi, N., Allen, I., Demirov, E., De Mey, P., Korres, G., Lascaratos, A., Le Traon, P. Y., Maillard, C., Manzella, G., and Tziavos, C.: The Mediterranean ocean Forecasting System:

30 first phase of implementation (1998-2001), Ann. Geophys., 21, 3-20, 2003.

Rew, R. K., Davis, G. P., Emmerson, S., and Davies, H.: NetCDF User's Guide, an interface for Data Access, version 3, http://www.unidata.ucar.edu/software/netcdf/docs/index.html, 1997.

\section{OSD}

3, 1609-1621, 2006

Relocatable model in MFS

A. Russo and

A. Coluccelli

\section{Title Page}

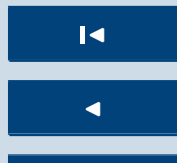

\section{Full Screen / Esc}

Printer-friendly Version

Interactive Discussion

EGU 
Robinson, A. R., Lermusiaux, P. J. F., and Sloan, N. Q.: Data assimilation, in: The Sea: The Global Coastal Ocean I, edited by Brink, K. H. and Robinson, A. R., 10, John Wiley \& Sons, New York, NY, 541-594, 1998.

Robinson, A. R.: Forecasting and simulating coastal ocean processes and variabilities with the Harvard Ocean Prediction System, in: Coastal Ocean Prediction, edited by: Mooers, C. N. K., AGU Coastal and Estuarine Studies Series, 56, Amer. Geophys. Union, Washington D.C., 77-100, 1999.

Shapiro, R.: Smoothing, filtering and boundary effects, Rev. Geophys. Space Phys., 8, 359387, 1970.

10 Spall, M. A. and Robinson, A. R.: Regional primitive equation studies of the Gulf Stream meander and ring formation region, J. Phys. Oceanogr., 20, 7, 985-1016, 1990.

Steppeler ,J., Doms, G., Shatter, U., Bitzer, H. W., Gassmann, A., Damrath, U., and Gregoric, G. : Meso-gamma scale forecasts using the nonhydrostatic model LM, Meteorology and Atmospheric Physics, 82, 75-96, 2003.

Zavatarelli, M. and Pinardi, N.: The Adriatic Sea modelling system: a nested approach, Ann. Geophys., 21, 345-364, 2003.

OSD

3, 1609-1621, 2006

Relocatable model in MFS

\section{A. Russo and}

A. Coluccelli

\section{Title Page}
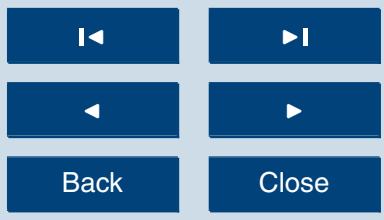

\section{Full Screen / Esc}

Printer-friendly Version

Interactive Discussion 


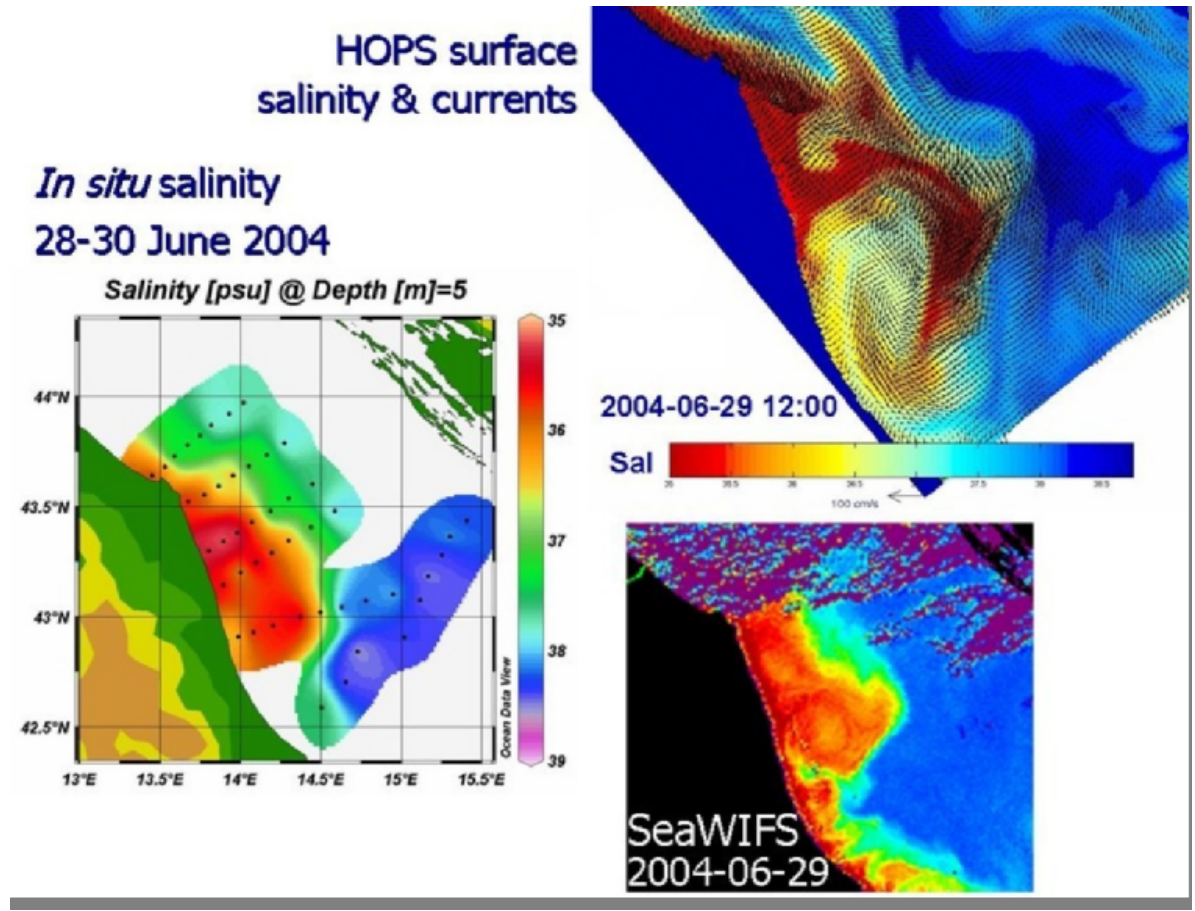

3, 1609-1621, 2006

Relocatable model in MFS
A. Russo and
A. Coluccelli

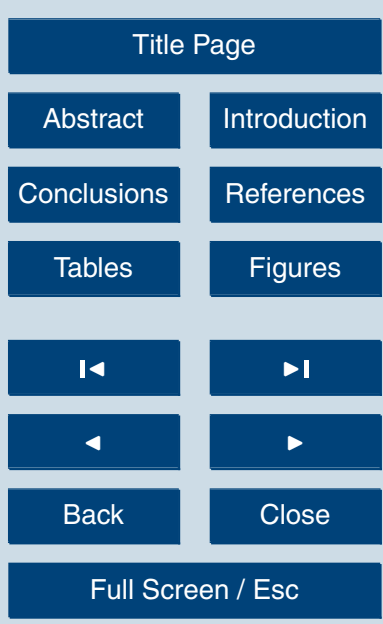

Fig. 1. Composite representing surface salinity and currents simulated by the relocatable model (right upper corner), in situ surface salinity (R/V Dallaporta survey, ISMAR-CNR, Ancona; left) and SeaWIFS ocean colour (acquired and processed by ISAC-CNR, Rome, Italy; right lower corner); central date for all images is 29 June 2004.

Printer-friendly Version

Interactive Discussion 


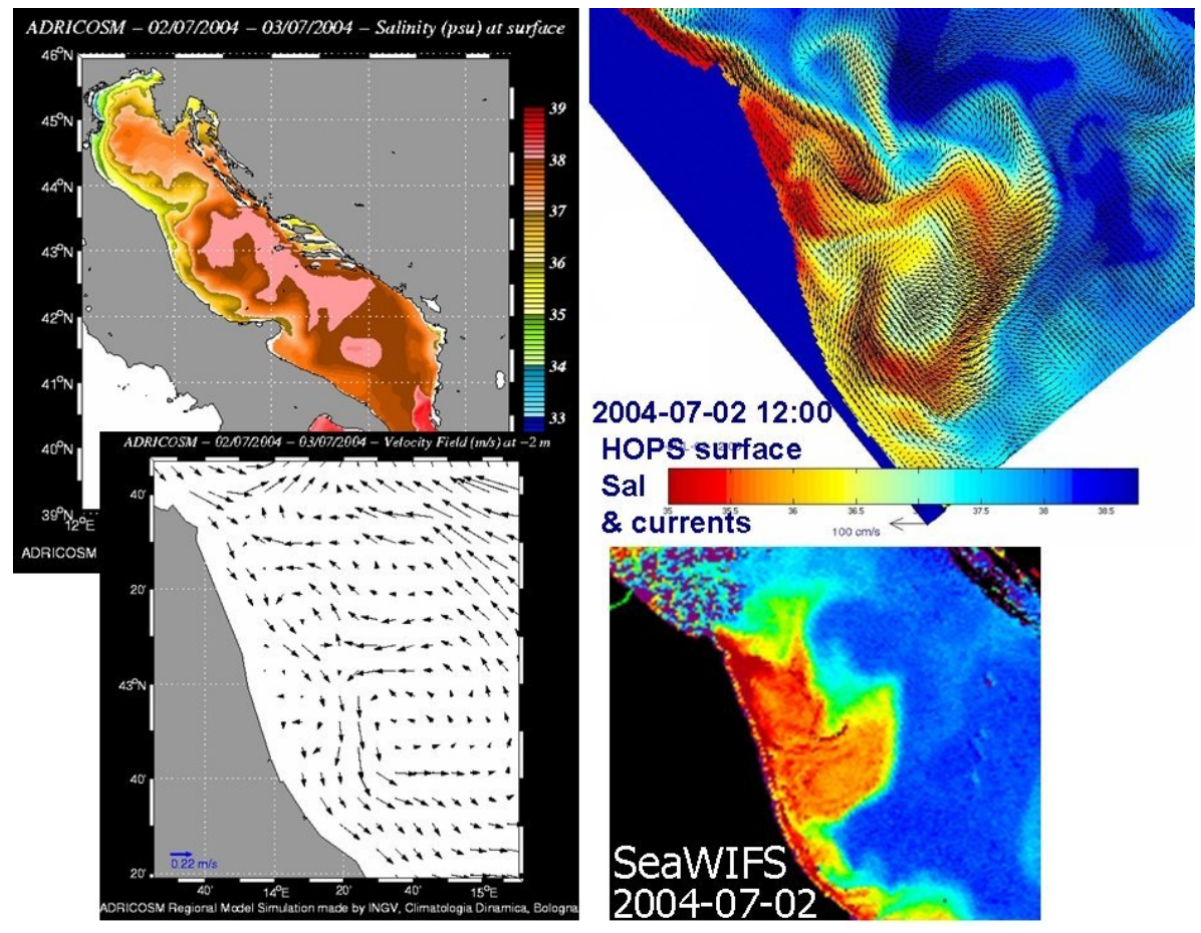

Fig. 2. Composite representing surface salinity and currents simulated by the relocatable model (right upper corner), surface salinity and currents hindcast by AREG (left) and SeaWIFS ocean colour (acquired and processed by ISAC-CNR, Rome, Italy; right lower corner); central date for all images is 2 July 2004.
OSD

3, 1609-1621, 2006

Relocatable model in MFS
A. Russo and
A. Coluccelli

Title Page

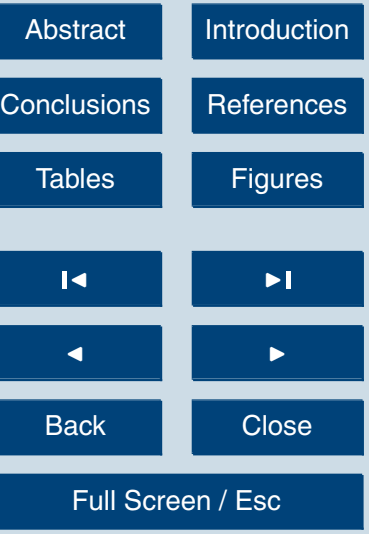

Printer-friendly Version

Interactive Discussion 